\title{
EFFECTS OF THE DIRECT RENIN INHIBITOR ALISKIREN ON OXIDATIVE STRESS IN ISOLATED RAT HEART
}

\author{
Sasa Plecevic ${ }^{1}$, Olga Pechanova ${ }^{2}$, Andrej Barta ${ }^{2}$, Aleksandra Vranic ${ }^{3}$, Jovana Jeremic ${ }^{3}$, Ljiljana Arsenijevic ${ }^{3}$, \\ Nevena Jeremic ${ }^{4}$, Vladimir Jakovljevic ${ }^{3}$, Maja Jevdjevic ${ }^{3}$, Dejan Stanojevic ${ }^{3}$ \\ ${ }^{1}$ Sports Medicine Association of Serbia, Belgrade, Serbia \\ ${ }^{2}$ Institute of Normal and Pathological Physiology, Slovak Academy of Sciences, Bratislava, Slovak Republic \\ ${ }^{3}$ Department of Physiology, Faculty of Medical Sciences, University of Kragujevac, Kragujevac, Serbia \\ ${ }^{4}$ Department of Pharmacy, Faculty of Medical Sciences, University of Kragujevac, Kragujevac, Serbia
}

\section{EFEITI DIREKTNOG RENINSIKOG INHIBITORA ALISKIRENA NA OKSIDATIVNI STRES IZOLOVANOG SRCA PACOVA \\ Saša Plećević ${ }^{1}$, Olga Pehanova ${ }^{2}$, Andrej Barta $^{2}$, Aleksandra Vranić $^{3}$, Jovana Jeremić ${ }^{3}$, Ljiljana Arsenijević ${ }^{3}$, Nevena Jeremić ${ }^{4}$, Vladimir Jakovljević3 ${ }^{3}$ Maja Jevđević3, Dejan Stanojević ${ }^{3}$ ${ }^{1}$ Udruženje za medicinu sporta Srbije, Beograd, Srbija \\ Institut za normalnu i patološku fiziologiju, Slovačka akademija nauka, Bratislava, Slovačka ${ }^{3}$ Katedra za fiziologiju, Fakultet medicinskih nauka, Univerzitet u Kragujevcu, Kragujevac, Srbija \\ ${ }^{4}$ Odsek za farmaciju, Fakultet medicinskih nauka, Univerzitet u Kragujevcu, Kragujevac, Srbija}

\section{ABSTRACT}

Increased activity of the renin-angiotensin-aldosterone system (RAAS) plays a significant role in the development and progression of various cardio-metabolic diseases, such as hypertension, atherosclerosis and heart failure. Aliskiren is the newest antihypertensive drug and the first orally active direct renin inhibitor to become available for clinical use. This study investigated the acute and direct effects of Aliskiren on different parameters of oxidative stress on isolated rat heart. The hearts of male Wistar albino rats $(n=24,8$ per experimental group, age 8 weeks, body mass 180-200 g), were excised and retrogradely perfused according to the Langendorff technique at a gradually increasing perfusion pressure (40-120 $\left.\mathrm{cmH}_{2} \mathrm{O}\right)$. Markers of oxidative stress $\left(\mathrm{NO}_{2}\right.$, TBARS, $\mathrm{H}_{2} \mathrm{O}_{2}$ and $\left.\mathrm{O}_{2}^{-}\right)$were measured spectrophotometrically after perfusion with three different concentrations of Aliskiren $(0.1 \mu \mathrm{M}, 1 \mu \mathrm{M}$, and $10 \mu \mathrm{M})$. The results demonstrated possible dose-dependent cardioprotective properties of Aliskiren, particularly with higher CPP. Lipid peroxidation (TBARS) levels decreased with the highest dose of Aliskiren and higher CPP, and the same trend was observed in nitrite $\left(\mathrm{NO}_{2}^{-}\right)$and hydrogen peroxide $\left(\mathrm{H}_{2} \mathrm{O}_{2}\right)$ levels. These findings indicate that the acute effects of Aliskiren do not likely promote the production of reactive oxygen species upon higher pressure with the highest dose. Aliskiren may exert beneficial effects on oxidative stress biomarkers.

Keywords: Aliskiren, Isolated rat heart, Langendorff technique, Oxidative stress

\section{SAŽETAK}

Povećana aktivnost rennin-angiotenzin-aldosteron sistema (RAAS) može da ima značajnu ulogu u razvoju i progresiji različitih kardio-metaboličkih bolesti kao što su hipertenzija, ateroskleroza i srčana insuficijencija. Aliskiren se ubraja u najnovije antihipertenzivne lekove i prvi je oralni direktni inhibitor renina koji je uveden u kliničku upotrebu. Prema tome, cilj ove studije je bio da ispita akutne i direktne efekte aliskirena na različite parametre oksidativnog stresa izolovanog srca pacova. U studiji su korišćeni Wistar albino pacovi (n = 24, 8 životinja u svakoj grupi) muškog pola, starosti 8 nedelja, telesne mase 180-200g. Nakon izolovanja, srca ovih pacova su retrogradno perfundovana prema Langendorff-ovoj tehnici uz postepeno povećanje perfuzionog pritiska (40-120 $\left.\mathrm{CmH}_{2} \mathrm{O}\right)$. Markeri oksidativnog stresa $\left(\mathrm{NO}_{2}^{-}, \mathrm{TBARS}, \mathrm{H}_{2} \mathrm{O}_{2} \mathrm{i}\right.$ $\left.\mathrm{O}_{2}^{-}\right)$su mereni spektrofotometrijski nakon perfuzije sa tri razli-

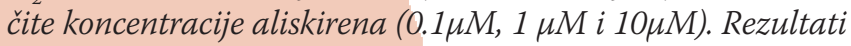
su pokazali da aliskiren pri najvišim vrednostima perfuzionog pritiska ostvaruje izvesna dozno-zavisna kardioprotektivna svojstva. Naime, nivoi indeksa lipidne peroksidacije (TBARS), nitrita $\left(\mathrm{NO}_{2}{ }^{-}\right)$i vodonik peroksida $\left(\mathrm{H}_{2} \mathrm{O}_{2}\right)$ su bili sniženi nakon administracije najveće doze aliskirena pri višim perfuzionim pritiscima. Ova saznanja ukazuju da akutno primenjeni aliskiren (pri višim dozama i perfuzionim pritiscima) ne stimuliše proizvodnju slobodnih radikala. Aliskiren može da ima pozitivne efekte na biomarkere oksidativnog stresa.

Ključne reči: aliskiren, izolovano srce pacova, oksidativni stres, tehnika po Langendorff-u

\section{ABBREVIATIONS}

ACEI - Angiotensin converting enzyme inhibitors ARB - Angiotensin receptor blockers AT - Angiotensin CF - Coronary flow cGMP - Cyclic guanosine 3',5'-monophosphate
DRI - Direct renin inhibitor

MDA - Malondialdehyde

NO - Nitric oxide

RAAS - Renin-angiotensin-aldosterone system

ROS - Reactive oxygen species 


\section{INTRODUCTION}

Increased activity of the renin-angiotensin-aldosterone system (RAAS) plays a significant role in the development and progression of various cardiometabolic diseases, such as hypertension, atherosclerosis, diabetes and heart failure (1). RAAS promotes vasoconstriction, sodium reabsorption, cardiac remodelling and other potentially detrimental effects $(2,3)$. Angiotensin II interaction with the AT1 receptor subtype and promotes oxidative stress, vascular smooth muscle migration, cardiomyocyte proliferation, hypertrophy and ventricular dilatation (4). Direct renin inhibitor blockade of RAAS at the rate-limiting step via reduction in plasma renin activity and levels of circulating angiotensin I and angiotensin II may be beneficial for cardiovascular risk in patients with essential hypertension and associated clinical conditions, such as diabetes and nephropathy $(5,6)$.

Aliskiren is the newest antihypertensive drug and the first orally active direct renin inhibitor (DRI) to become available for clinical use. The US Food and Drug Administration approved Aliskiren for clinical use in March 2007 (7). Essential hypertension is an important cause of death worldwide. Blockade of RAAS, which plays a significant role in the development of essential hypertension, is suboptimal in combination with angiotensin II (AT II)-converting enzyme inhibitors (ACEIs) or ATII type 1 receptor blockers (ARB) (8). However, whether Aliskiren is superior to conventional RAAS blockers in the prevention of heart and renal diseases is not known (9). Aliskiren is generally well tolerated, and it exhibits a placebo-like profile at doses from $75 \mathrm{mg}$ to $300 \mathrm{mg}$ (5). The plasma concentration of Aliskiren increases in a dose-dependent fashion, with peak concentrations after 3-6 hours. The average plasma half-life of Aliskiren is 23.7 hours, oral bioavailability is approximately $5 \%$ (95\% is excreted unchanged in faeces), and plasma steadystate levels are achieved after 5-8 days of treatment (1). Aliskiren is primarily eliminated unmetabolised via biliary excretion, and less than $1 \%$ is excreted in the urine (5). Several clinical trials confirmed the efficacy of Aliskiren on blood pressure reduction as a monotherapy $(10,11)$ and in combination therapy $(12,13)$.

Oxidative stress is a well-known phenomenon that plays an important role in the pathogenesis of various diseases and syndromes. Any imbalance between pro- and anti-oxidants in which pro-oxidants prevail is known as oxidative stress (14). Existing evidence supports the view that oxidative stress may play a crucial role in cardiac and vascular abnormalities in different types of cardiovascular diseases, and antioxidant therapy may be beneficial (15). Few studies investigated the influence of Aliskiren on oxidative stress, but recent studies in different models suggested that Aliskiren monotherapy or in combination reduces blood pressure by increasing NO (nitric oxide)-cGMP (cyclic guanosine $3^{\prime}, 5^{\prime}$-monophosphate) production (16), superoxide anion production and malondialdehyde (17).
Previous data on reactive oxygen species (ROS), such as superoxide anion radical $\left(\mathrm{O}_{2}^{-}\right)$, hydrogen peroxide $\left(\mathrm{H}_{2} \mathrm{O}_{2}\right)$, index of lipid peroxidation and nitrites $\left(\mathrm{NO}_{2}{ }^{-}\right)$, are not sufficient. Therefore, this study investigated the acute and direct effects of Aliskiren on different parameters of oxidative stress on isolated rat hearts from adult male rats.

\section{MATERIALS AND METHODS}

\section{Isolated rat heart preparation}

The hearts of male Wistar albino rats $(\mathrm{n}=24,8$ per experimental group, age 8 weeks, body mass $180-200$ g) were euthanized via cervical dislocation (Schedule 1 of the Animals/Scientific procedures, Act 1986, United Kingdom) after short ketamine/xylazine narcosis. Emergency thoracotomy and sudden cardiac arrest were performed via superfusion with ice-cold isotonic saline. Normal heart rhythm was restored, and an entrance to the left atrium of the heart was created through the damaged mitral valve. Hearts were retrogradely perfused according to the Langendorff technique at a gradually increasing perfusion pressure $\left(40 \mathrm{cmH}_{2} \mathrm{O}-120 \mathrm{cmH}_{2} \mathrm{O}\right)$. Hearts were perfused with a Krebs-Henseleit solution composed of: $\mathrm{NaCl} 118$ $\mathrm{mM}, \mathrm{KCl} 4.7 \mathrm{mM}, \mathrm{CaCl}_{2} \times 2 \mathrm{H}_{2} \mathrm{O} 2.5 \mathrm{mM}, \mathrm{MgSO}_{4} \times 7 \mathrm{H}_{2} \mathrm{O}$ $1.7 \mathrm{mM}, \mathrm{NaHCO}_{3} 25 \mathrm{mM}, \mathrm{KH}_{2} \mathrm{PO}_{4} 1.2 \mathrm{mM}$, and glucose $5.5 \mathrm{mM}$, equilibrated with $95 \% \mathrm{O}_{2} / 5 \% \mathrm{CO}_{2}$ and warmed to $37^{\circ} \mathrm{C}(\mathrm{pH} 7.4)$.

\section{Physiological assay and experimental protocol}

A 30-min perfusion stabilisstabilization period was performed. CPP was lowered to $60 \mathrm{cmH}_{2} \mathrm{O}$ after an equilibration period $\left(70 \mathrm{cmH}_{2} \mathrm{O}\right)$ and gradually increased to $80 \mathrm{cmH}_{2} \mathrm{O}, 100 \mathrm{cmH}_{2} \mathrm{O}$, and $120 \mathrm{cmH}_{2} \mathrm{O}$, then finally lowered to $40 \mathrm{cmH}_{2} \mathrm{O}$. Measurements were performed at each perfusion pressure using pure a Krebs-Henseleit solution and immediately followed by perfusion with active components (different concentrations of Aliskiren) to avoid time-dependent adverse effects. Groups were assigned by the concentration of Aliskiren given in the Krebs-Henseleit perfusate: the hearts of the first group were perfused with $0.1 \mu \mathrm{M}$ Aliskiren; the second group with $1 \mu \mathrm{M}$; and the third group with $10 \mu \mathrm{M}$. Each heart was its own control. Coronary flow (CF) was considered stable when three repeated values of CF were identical. The following markers of oxidative stress were measured spectrophotometrically in the collected samples of coronary venous effluent:

1. Nitrites $\left(\mathrm{NO}_{2}^{-}\right)$

2. Index of lipid peroxidation (measured as TBARS thiobarbituric acid-reactive substances)

3. Hydrogen peroxide $\left(\mathrm{H}_{2} \mathrm{O}_{2}\right)$ and

4. Superoxide anion radical $\left(\mathrm{O}_{2}^{-}\right)$ 
The Faculty of Medical Sciences Ethics Committee for the welfare of experimental animals, University of Kragujevac approved the experimental protocol.

\section{Biochemical assays}

\section{Determination of nitrites $\left(\mathrm{NO}_{2}^{-}\right)$}

Nitric oxide decomposes rapidly to form stable metabolite nitrite/nitrate products. The nitrite level $\left(\mathrm{NO}_{2}{ }_{2}\right)$ was measured and used as an index of nitric oxide (NO) production using Griess's reagent. A total of $0.5 \mathrm{ml}$ of perfusate was precipitated with $200 \mu \mathrm{l}$ of $30 \%$ sulphosalicylic acid, vortexed for $30 \mathrm{~min}$, and centrifuged at $3000 \mathrm{x}$ g. Equal volumes of the supernatant and Griess's reagent, containing $1 \%$ sulphanilamide in $5 \%$ phosphoric acid/ 0.1 $\%$ naphthalene ethylenediamine dihydrochloride, was added and incubated for $10 \mathrm{~min}$ in the dark and measured at $543 \mathrm{~nm}$. Nitrite levels were calculated using sodium nitrite as the standard (18).

\section{TBARS determination (index of lipid peroxidation)}

The degree of lipid peroxidation in the coronary venous effluent was estimated by TBARS using $1 \%$ thiobarbituric acid in $0.05 \mathrm{NaOH}$ incubated with the coronary effluent at $100^{\circ} \mathrm{C}$ for $15 \mathrm{~min}$ and measured at $530 \mathrm{~nm}$. The KrebsHenseleit solution was used as a blank probe (19).

Determination of hydrogen peroxide $\left(\mathrm{H}_{2} \mathrm{O}_{2}\right)$

Measurements of hydrogen peroxide $\left(\mathrm{H}_{2} \mathrm{O}_{2}\right)$ were based on the oxidation of phenol red by hydrogen peroxide, in a reaction catalysed by horseradish peroxidase (HRPO). A volume of $200 \mu \mathrm{l}$ of perfusate was precipitated with 800 $\mathrm{ml}$ of a freshly prepared phenol red solution, and $10 \mu \mathrm{l}$ of (1:20) HRPO (made ex tempore) was added. An adequate volume of Krebs-Henseleit solution was used in blank probes (instead of coronary venous effluent). The level of $\mathrm{H}_{2} \mathrm{O}_{2}$ was measured at $610 \mathrm{~nm}(20)$.

\section{Determination of superoxide anion radical $\left(\mathrm{O}_{2}{ }^{-}\right)$}

Superoxide anion radical $\left(\mathrm{O}_{2}^{-}\right)$levels were measured using a nitro blue tetrazolium reaction in TRIS buffer with coronary venous effluent at $550 \mathrm{~nm}$. The Krebs-Henseleit solution was used as a blank probe (21).

\section{Drug}

Aliskiren was used as pure drug (Hangzhou Holypharm Biotech CO., LTD).

\section{Statistical analysis}

Experimental data are expressed as the mean value (X) \pm standard deviation (SD). Paired samples t tests were used to test the statistical significance of the results and confirm the hypotheses. A database analysis of the results was performed using the software package SPSS 18th version (SPSS Inc., Chicago, IL, USA). P values lower than 0.05 $(\mathrm{p}<0.05)$ were considered significant, and $\mathrm{p}$ values lower than $0.01(\mathrm{p}<0.01)$ were considered highly significant.

\section{RESULTS}

Nitrites $\left(\mathrm{NO}_{2}{ }^{-}\right)$

The administration of $10 \mu \mathrm{M}$ Aliskiren induced a statistically significant decrease in $\mathrm{NO}_{2}$ - release at $\mathrm{CPP}=120$ $\mathrm{cmH}_{2} \mathrm{O}$. $\mathrm{NO}_{2}$ - release did not change significantly during the administration of $0.1 \mu \mathrm{M}$ and $1 \mu \mathrm{M}$ Aliskiren for any $\mathrm{CPP}$ valu ce compared with the control conditions (Figure $1 \mathrm{~A}, 1 \mathrm{~B}, 1 \mathrm{C})$.

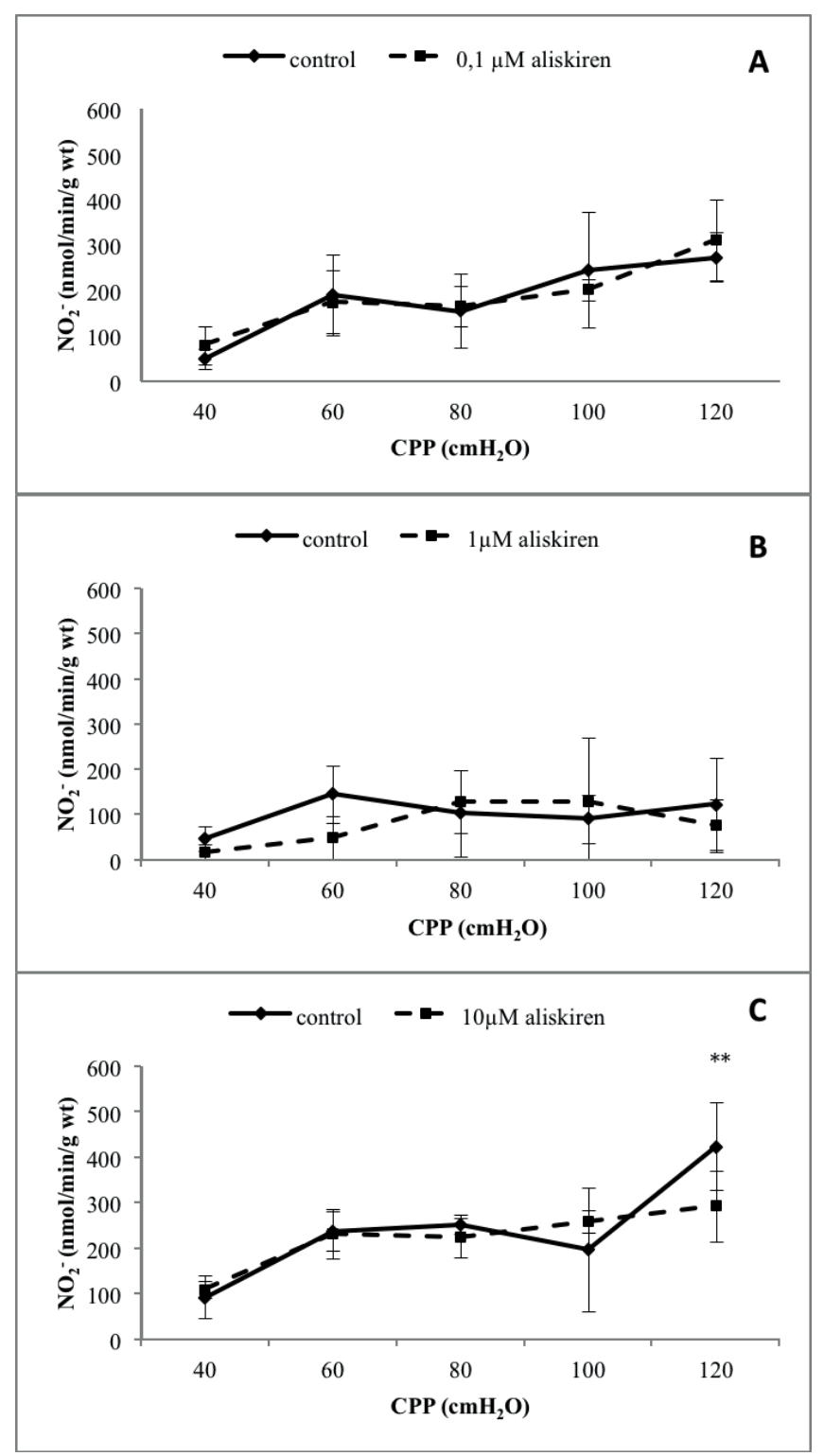

Figure 1A-C. The effects of $0.1 \mu \mathrm{M}$ Aliskiren (1A), $1 \mu \mathrm{M}$ Aliskiren (1B) and $10 \mu \mathrm{M}$ Aliskiren $(1 \mathrm{C})$ on the oxidative stress parameter $\mathrm{NO}_{2}-$ Values are representedmean as the means $\pm \mathrm{SE} ;{ }^{*} \mathrm{p}<0.05,{ }^{* *} \mathrm{p}<0.01$. 


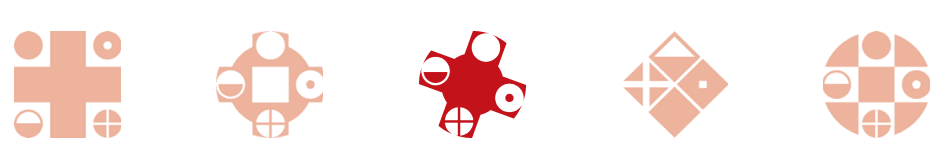

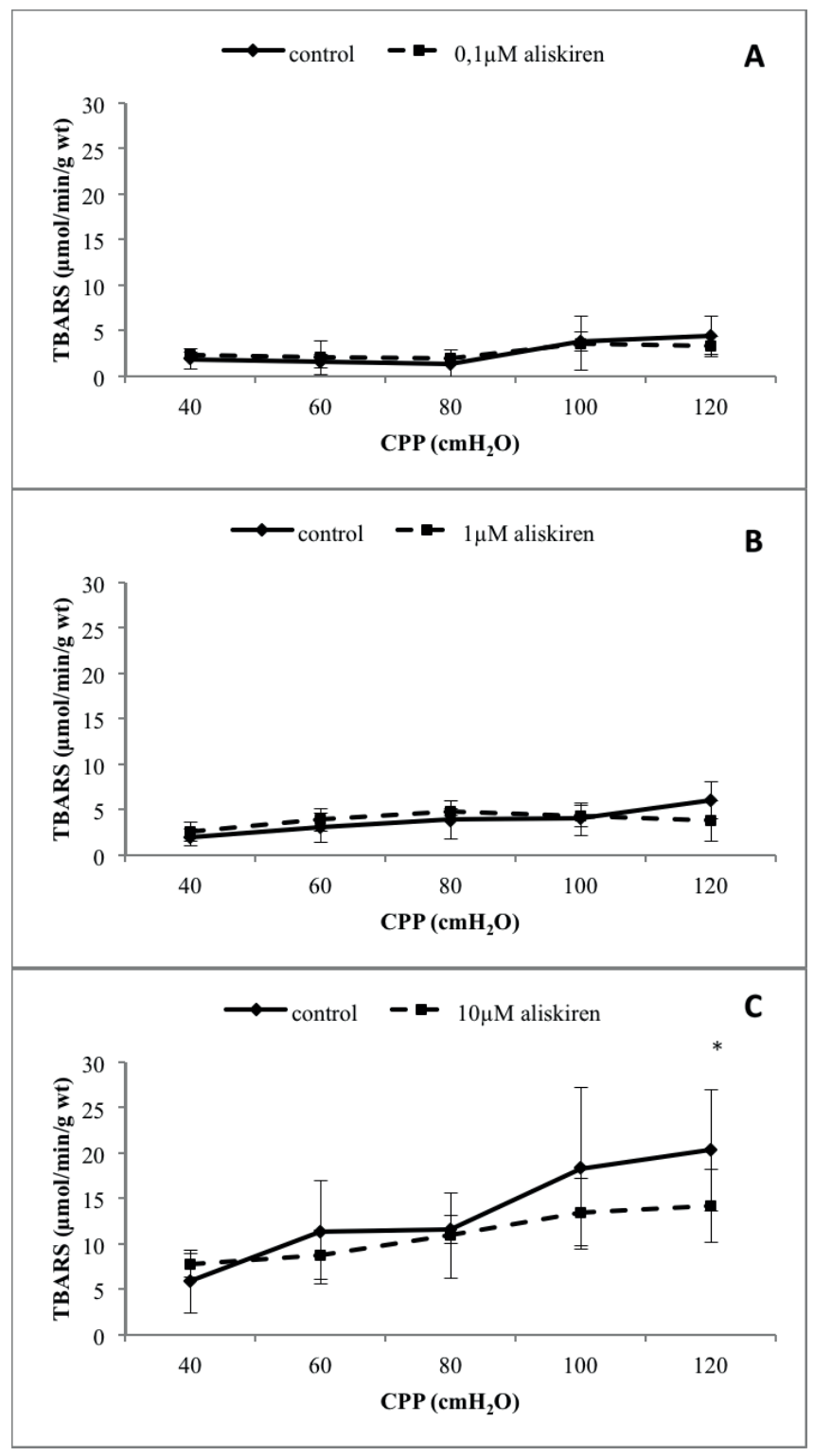

Figure 2A-C. The effects of $0.1 \mu \mathrm{M}$ Aliskiren (2A), $1 \mu \mathrm{M}$ Aliskiren (2B) and $10 \mu \mathrm{M}$ Aliskiren $(2 \mathrm{C})$ on the oxidative stress parameter TBARS. Values represent means $\pm \mathrm{SE}$; ${ }^{*} \mathrm{p}<0.05$, ${ }^{* * *} \mathrm{p}<0.01$.

\section{Index of lipid peroxidation (TBARS)}

The administration of $10 \mu \mathrm{M}$ Aliskiren induced a statistically significant decrease in lipid peroxidation at $\mathrm{CPP}=$ $120 \mathrm{cmH}_{2} \mathrm{O}$. There were no statistically significant changes in TBARS values during the application of $0.1 \mu \mathrm{M}$ Aliskiren or $1 \mu \mathrm{M}$ Aliskiren over the entire $\mathrm{CPP}$ range (Figure $2 \mathrm{~A}, 2 \mathrm{~B}, 2 \mathrm{C})$.

\section{Hydrogen peroxide $\left(\mathrm{H}_{2} \mathrm{O}_{2}\right)$}

The administration of $10 \mu \mathrm{M}$ Aliskiren induced a statistically significant decrease in $\mathrm{H}_{2} \mathrm{O}_{2}$ release at $\mathrm{CPP}=100$ $\mathrm{cmH}_{2} \mathrm{O}$. There were no statistically significant changes in $\mathrm{H}_{2} \mathrm{O}_{2}$ values during the application of $0.1 \mu \mathrm{M}$ Aliskiren or 1 $\mu \mathrm{M}$ Aliskiren over the entire CPP range (Figure 3A, 3B, 3C).

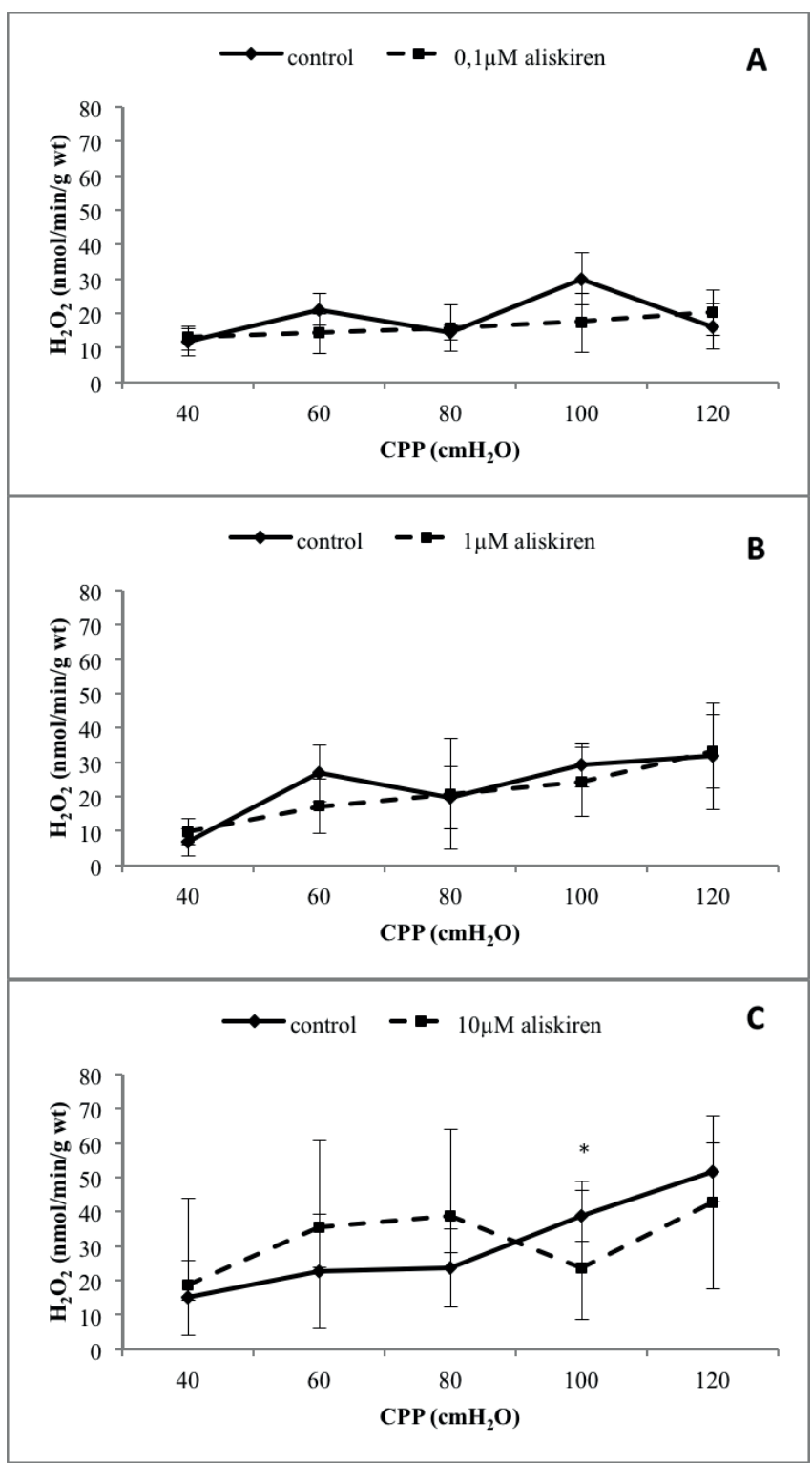

Figure 3A-C. The effects of $0.1 \mu \mathrm{M}$ Aliskiren (3A), $1 \mu \mathrm{M}$ Aliskiren (3B) and $10 \mu \mathrm{M}$ Aliskiren $(3 \mathrm{C})$ on the oxidative stress parameter $\mathrm{H}_{2} \mathrm{O}_{2}$. Values represent means $\pm \mathrm{SE} ;{ }^{*} \mathrm{p}<0.05,{ }^{*} \mathrm{p}<<0.01$.

\section{Superoxide anion radical $\left(\mathrm{O}_{2}^{-}\right)$}

No statistically significant changes in $\mathrm{O}_{2}^{-}$release were observed after $0.1 \mu \mathrm{M}, 1 \mu \mathrm{M}$ and $10 \mu \mathrm{M}$ Aliskiren administration over the entire CPP range (Figure 4A, 4B, 4C).

\section{DISCUSSION}

Hypertension is the disease that is most responsible for mechanical stress on the heart because of increased arterial pressure and structural and functional alterations of its target organs (22). Long-term hypertension often results in left ventricular hypertrophy, but antihypertensive drugs, including ACEI, ARB and calcium channel antagonists, 

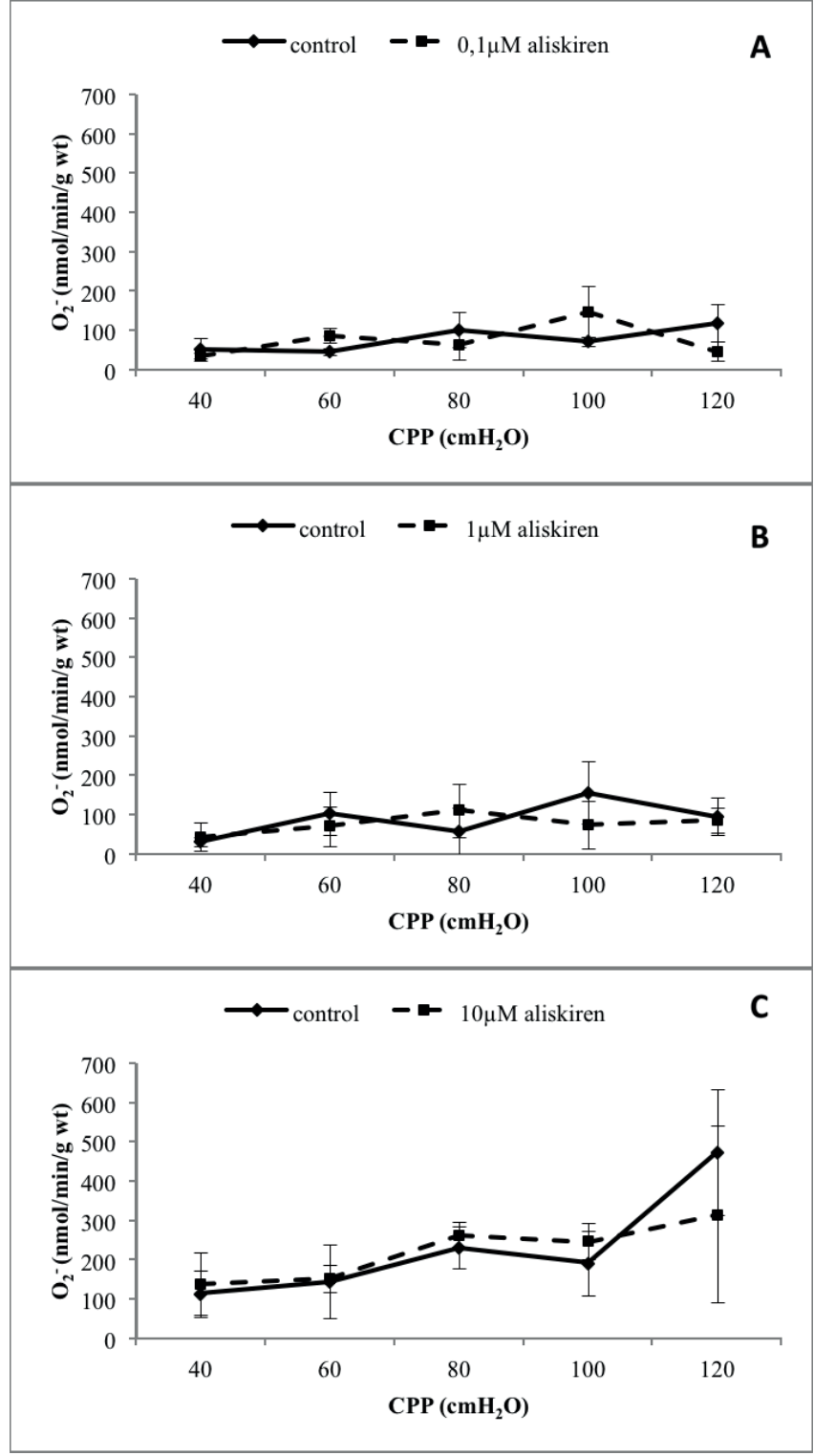

Figure 4A-C. The effects of $0.1 \mu \mathrm{M}$ Aliskiren (4A), $1 \mu \mathrm{M}$ Aliskiren (4B) and $10 \mu \mathrm{M}$ Aliskiren $(4 \mathrm{C})$ on the oxidative stress parameter $\mathrm{O}_{2}^{-}$. Values represent means $\pm \mathrm{SE}$; ${ }^{*} \mathrm{p}<0.05$, ${ }^{* *} \mathrm{p}<0.01$.

exert inhibitory effects on cardiac hypertrophy. However, disease progression and subsequent cardiac dysfunction remain a significant problem in hypertensive subjects (23). Prolonged hypertension also causes structural alterations of the vascular wall, which are characterized by endothelial dysfunction, extracellular matrix deposition, medial layer thickening due to hypertrophy/hyperplasia, and vascular smooth muscle cell migration. There is increasing interest in the development of new therapeutic possibilities against hypertension. One recent addition to the family of RAAS blockers was Aliskiren, which is a DRI that is indicated for the treatment of hypertension. Several studies demonstrated that Aliskiren, as first orally active DRI, could be used as a monotherapy and in combination with other agents to lower blood pressure (24). Some studies estimated that once daily Aliskiren administration reduced hypertension compared with ACEI, ARB, and diuretics (25-29). Aliskiren is the newest antihypertensive drug, and only a few studies evaluated the influence of Aliskiren on oxidative stress markers.

Several studies investigated Aliskiren and found positive antihypertensive effects (30-32), but no studies investigated the influence of acute Aliskiren administration on the production of oxygen-free radicals in an isolated rat heart.

Yamamoto et al. used a mouse model of renal and cardiac tissue and demonstrated that Aliskiren and valsartan were associated with significant reductions in oxidative stress in these tissues and the combination of these two drugs improved cardiovascular and renal injuries in endothelial NO synthase-deficient mice, which are associated with a greater attenuation of tissue oxidative stress markers (33). Imanishi et al. noted that Aliskiren treatment exhibited protective effects on endothelial function and atherosclerotic changes and co-treatment with an angiotensin II receptor blocker exhibited additive protective effects on both conditions (34).

The present study examined the effects of acute Aliskiren administration $(0.1 \mu \mathrm{M}, 1 \mu \mathrm{M}$, and $10 \mu \mathrm{M})$ on oxidative stress biomarkers in isolated rat hearts.

Our study investigated $\mathrm{NO}_{2}{ }^{-}$and demonstrated statistically significant changes, especially at the highest Aliskiren concentration. $\mathrm{NO}_{2}{ }^{-}$levels were lower than control values (Fig 1C). Luis et al. investigated chronic Aliskiren administration and Aliskiren in combination with Amlodipine in diabetic rats and demonstrated that NO levels increased after Aliskiren administration individually and as a combined therapy (16).

Additionally, TBARS values decreased significantly after $10 \mu \mathrm{M}$ Aliskiren administration compared to control (Fig 2C). Kamal investigated the effect of 4 weeks Aliskiren administration on TBARS in rat liver tissue homogenates and demonstrated increased TBARS levels, which is similar to our result (35). Lipid peroxidation was also increased in an experimental study using malondialdehyde (MDA) as an end product of polyunsaturated fatty acid oxygenation, which also correlates with our findings (15).

Administration of the highest dose of Aliskiren $(10 \mu \mathrm{M})$ slightly increased the measured values at lower CPP, but a significant decrease in parameter values was observed at $\mathrm{CPP}=100 \mathrm{cmH}_{2} \mathrm{O}$ (Fig 3C).

Superoxide anion radical levels were similar to Zang et al. who investigated chronic effects of Aliskiren on myocardial ischaemia/reperfusion injury in spontaneously hypertensive rats. This study recorded increased values of oxidative stress parameters in a control group of rats that did not receive Aliskiren. Aliskiren abolished the increased superoxide anion production in the experimental group (17). However, our results did not demonstrate any statistically significant differences, but the Figure for this parameter shows that the highest dose exhibited the lowest values (Fig 4C). 
Our data may be significant because few studies examined the influence of acute Aliskiren administration on the production oxidative stress parameters, especially of $\mathrm{H}_{2} \mathrm{O}_{2}$, in isolated rat hearts.

\section{CONCLUSIONS}

The results of the present study provide important insights into the acute and direct effects of Aliskiren on oxidative stress biomarkers in isolated rat hearts. Our results demonstrated that acute Aliskiren effects do not promote the production of reactive oxygen species. Aliskiren may exert beneficial effects on the balance of pro- and antioxidants. However, further research on chronic Aliskiren administration is needed to provide a clearer explanation of this phenomenon.

\section{ACKNOWLEDGMENT}

This work was supported by the Faculty of Medical Sciences, University of Kragujevac (Junior Project 01/2015)

\section{REFERENCES}

1. Angeli F, Reboldi G, Mazzotta G, et al. Safety and efficacy of aliskiren in the treatment of hypertension and associated clinical conditions. Curr Drug Saf. 2012;7(1):76-85

2. Dzau V. The cardiovascular continuum and renin-angiotensinaldosterone system blockade. J HypertensSuppl. 2005; 23: S9-17.

3. Pagliaro P, Penna C. Rethinking the renin-angiotensin system and its role in cardiovascular regulation. Cardiovasc Drugs Ther. 2005; 19: 77-87.

4. Angeli F, Reboldi G, Poltronieri C et al. Efficacy and safety profile of aliskiren: practical implications for clinicians. Curr Drug Saf. 2014; 9(2): 106-17.

5. Sen S, Sabırlı S, Ozyiğit T, Uresin Y. Aliskiren: review of efficacy and safety data with focus on past and recent clinical trials. TherAdv Chronic Dis. 2013; 4(5): 232-41.

6. Yoshitomi Y, Kawanishi K, Yamaguchi A, et al. Effectiveness of the direct renin inhibitor, aliskiren, in patients with resistant hypertension. Int Heart J. 2013; 54(2): 88-92.

7. Frampton JE, Curran MP. Aliskiren: a review of its use in the management of hypertension. Drugs. 2007; 67(12): 1767-92.

8. Zaporowska-Stachowiak I, Hoffmann K, Bryl W, Minczykowski A. Aliskiren - an alternative to angiotensinconverting enzyme inhibitors or angiotensin receptor blockers in the therapy of arterial hypertension. Arch Med Sci. 2014; 10(4): 830-6.

9. Maibaum J, Feldman DL. Renin inhibitors as novel treatments for cardiovascular disease. Expert Opin Ther Pat. 2003; 13: 589-603.
10. Fogari R, Zoppi A. New class of agents for treatment of hypertension: focus on direct renin inhibition. Vasc Health Risk Manag. 2010; 6: 869-82.

11. Lizakowski S, Tylicki L, Rutkowski B. Direct renin inhibition - a promising strategy for renal protection? Med SciMonit. 2013; 19: 451-7.

12. Oparil S, Yarows SA, Patel S, Fang H, Zhang J, Satlin A. Efficacy and safety of combined use of aliskiren and valsartan in patients with hypertension: a randomised, double-blind trial. Lancet. 2007; 370: 221-9.

13. McMurray JJV, Pitt B, Latini R et al. Effect of the oral direct renin inhibitor aliskiren in patients with symptomatic heart failure. Circ Heart Fail. 2008; 1: 17.

14. Ben-Menachem E, Kyllerman M, Marklund S. Superoxide dismutase and gluthatione peroxidase function in progressive myoclonus epilepsies. Epilepsy Res. 2000; 40: 33-9.

15. Naranjan SD, Temsah MR, Netticadan T. Role of oxidative stress in cardiovascular diseases. Journal of hypertension. 2000; 18.6: 655-73.

16. Matavelli LC, Siragy HM. Reduction of aldosterone production improves renal oxidative stress and fibrosis in diabetic rats. J Cardiovasc Pharmacol. 2013; 61(1): 17-22.

17. Wen Zhang, Yi Han, GuoliangMeng, et al. Direct Renin Inhibition With Aliskiren Protects Against Myocardial Ischemia/Reperfusion Injury by Activating Nitric Oxide Synthase Signaling in Spontaneously Hypertensive Rats. J Am Heart Assoc. 2014; 3(1): e000606.

18. Green, LC, Wagner DA, Glogowski J, Skipper, P.L., Wishnok, J.S., Tannenbaum, S.R. Analysis of nitrate, nitrite and $[15 \mathrm{~N}]$ nitrate in biological fluids. Anal. Biochem. 1982; 126: 131-8.

19. Ohkawa H, Ohishi N, Yagi K. Assay for lipid peroxides in animal tissues by thiobarbituric acid reaction. Anal, Biochem. 1979; 95: 351-8.

20. Pick E, Keisari Y. A simple colorimetric method for the measurement of hydrogen peroxide produced by cells in culture. J. Immunol. Methods. 1980; 38: 161-70.

21. Auclair C, Voisin E. Nitroblue tetrazolium reduction. In: Handbook of methods for oxygen radical research, (Ed R.A. Greenvvald). 1985; 123-32. CRC Press, Boca Raton.

22. Frohlich ED. State of the Art lecture. Risk mechanisms in hypertensive heart disease. Hypertension. 1999; 34: 782-9.

23. Weng LQ, Zhang WB, Ye Y et al. Aliskiren ameliorates pressure overload-induced heart hypertrophy and fibrosis in mice. Acta Pharmacol Sin. 2014; 35(8): 1005-14.

24. Santuzzi CH, Tiradentes RV, Mengal V et al. Combined aliskiren and L-arginine treatment has antihypertensive effects and prevents vascular endothelial dysfunction in a model of renovascular hypertension. Braz J Med Biol Res. 2015; 48(1): 65-76.

25. Savvatis K, Westermann D, Schultheiss HP, Tschope C. First-line treatment of hypertension: critical appraisal of potential role of aliskiren and hydrochlorothiazide in a fixed combination. Integr Blood Press Control. 2010; 3: $163-70$. 
26. Duprez DA, Davis P, Botha J. The Ageless Study: The effect of aliskiren vs ramipril alone or in combination with hydrochlorothiazide and amlodipine in patients $=65$ years of age with systolic hypertension. Circulation.2008; 118: 886-7.

27. Stanton A, Jensen C, Nussberger J, O’Brien E. Blood pressure lowering in essential hypertension with an oral renin inhibitor, aliskiren. Hypertension. 2003; 42: 1137-43.

28. Gradman AH, Schmieder RE, Lins RL, Nussberger J, Chiang Y, Bedigian MP. Aliskiren, a novel orally effective renin inhibitor, provides dose-dependent antihypertensive efficacy and placebo-like tolerability in hypertensive patients. Circulation. 2005; 111: 1012-8.

29. Schmieder RE, Philipp T, Guerediaga J et al. Long-term antihypertensive efficacy and safety of the oral direct renin inhibitor aliskiren: a 12-month randomized, double-blind comparator trial with hydrochlorothiazide. Circulation. 2009; 119: 417-25.

30. Lu H, Rateri DL, Feldman DL et al. Renin inhibition reduces hypercholesterolemia-induced atherosclerosis in mice. J Clin Invest. 2008; 118(3): 984-93.
31. Renke M, Lizakowski S, Tylicki L, et al. Aliskiren attenuates oxidative stress and improves tubular status in non-diabetic patients with chronic kidney diseasePlacebo controlled, randomized, cross-over study. Adv Med Sci. 2014; 59(2): 256-60.

32. Imanishi T, Tsujioka H, Ikejima $H$, et al. Renin inhibitor aliskiren improves impaired nitric oxide bioavailability and protects against atherosclerotic changes. Hypertension. 2008; 52(3): 563-72.

33. Yamamoto E, Kataoka K, Dong YF et al. Aliskiren enhances the protective effects of valsartan against cardiovascular and renal injury in endothelial nitric oxide synthase-deficient mice. Hypertension. 2009; 54(3): 633-8.

34. Imanishi T, Tsujioka H, Ikejima $\mathrm{H}$ et al. Renin inhibitor aliskiren improves impaired nitric oxide bioavailability and protects against atherosclerotic changes. Hypertension. 2008; 52(3): 563-72.

35. Kamal S. Aliskiren Augments the Activities of AntiOxidant Enzymes in Liver Homogenates of DOCA Salt-Induced Hypertensive Rats. SciRes. 2014; 2: 92-9. 